\title{
Gastrocytoprotection by colloidal bismuth subcitrate (De-Nol) and sucralfate. Role of endogenous prostaglandins
}

\author{
S J KONTUREK, T RADECKI, IRENEUSZ PIASTUCKI, \\ TOMASZ BRZOZOWSKI, AND DANUTA DROZDOWICZ
}

From the Institute of Physiology Medical Academy, Kraków, Poland

SUMmARY This study compares the gastroprotective effects of colloidal bismuth subcitrate (DeNol) with those of sucralfate and a methylated analogue of prostaglandin $E_{2}\left(P_{G} E_{2}\right)$ against acute gastric lesions induced by acidified aspirin and absolute ethanol in rats. Both De-Nol and sucralfate given orally prevented dose dependently the formation of gastric lesions by these ulcerogens, DeNol being, respectively, twice and seven times more potent, on a weight basis, than sucralfate. As the gastroprotective activities of both De-Nol and sucralfate on ethanol lesions can be reversed by pretreatment with indomethacin and as De-Nol and sucralfate increase the mucosal generation and luminal release of $\mathrm{PGE}_{2}$, we postulate that mucosal prostaglandins may be involved in the mechanism of action of these drugs on the gastric mucosa.

Bismuth compounds have been used for over two centuries for the treatment of various gastrointestinal disorders because of their local protective, demulcent, and antacid properties. The more recently developed colloidal bismuth subcitrate (De-Nol), known also as CBS, offered a new approach in peptic ulcer therapy because of its selective binding to the ulcer base, the protection against acid-pepsin attack and its activity against pyloric campylobacter. ${ }^{1-5}$

De-Nol was reported to protect the gastric mucosa against various ulcerogens in animals ${ }^{12}$ and to be effective in promoting the healing of gastric ${ }^{6}$ and duodenal ulcers ${ }^{7}$ in man. Moreover, ulcer relapse has been shown to be reduced after healing with De-Nol compared with healing with $\mathrm{H}_{2}$-antagonists. ${ }^{89}$ The mechanism of these effects has not been fully elucidated. Because prostaglandins are known to exhibit both anti-ulcer and protective activities ${ }^{10}$ and sucralfate is considered to be a standard protective agent in experimental animals ${ }^{112}$ and effective drug in the healing and the reduction of the recurrency of peptic ulcer in man, ${ }^{13}{ }^{14}$ we decided to compare the gastroprotective effects of De-Nol and sucralfate with those

Address for correspondence: Prof Dr S J Konturek, Institute of Physiology, 31-531 Kraków, ul. Grzegórzecka 16, Poland.

Received for publication 3 June 1986. of prostaglandins and to determine the influence of these agents on mucosal generation and release of prostaglandin.

\section{Methods}

GASTRIC SECRETORY STUDIES

The effect of De-Nol, sucralfate and methylated prostaglandin analogue on gastric secretion were studied in conscious rats prepared with a gastric fistula about one month earlier. They were fasted for about 24 hours and then placed in Bollman cages. The cannulas of the fistulas were opened and then the stomachs were washed out with saline. The basal gastric juice was collected for five 30 minute periods. After collecting three control 30 minute samples DeNol $(80 \mathrm{mg} / \mathrm{kg})$, sucralfate $(400 \mathrm{mg} / \mathrm{kg})$ or 16,16 dimethyl $\mathrm{PGE}_{2}(10 \mu \mathrm{g} / \mathrm{kg})$ dissolved in $1 \mathrm{ml}$ water was introduced intragastrically for a 30 minute period, the gastric fistula being closed for 30 minutes. After this interruption the fistula was opened again, the stomach drained for five minutes and this collection discarded. The collection was continued for two 30 minute periods with saline infused sc at a rate of $4 \mathrm{ml} / \mathrm{h}$ throughout. Acid and pepsin secretion was measured in each 30 minute sample as described ${ }^{15}$ and expressed as outputs/60 minute period after 
administration of tested drugs or $1 \mathrm{ml}$ of water (control). All secretory tests were done on the same 10 gastric fistula rats weighing about $250 \mathrm{~g}$.

\section{PRODUCTION OF GASTRIC MUCOSAL LESIONS}

Acute gastric ulcerations were induced in Wistar rats (180-200 g bw) by intragastric administration of absolute ethanol or acidified ASA.

Absolute ethanol was administered in 24 hour fasted rats in a volume of $1 \mathrm{ml}$ using a metal orogastric tube. ${ }^{16}$ One hour later the animals were killed by a blow to the head, the stomach was removed and the number and area of gastric necrotic lesions were measured planimetrically (Morphomat, Carl Zeiss, Berlin, Germany).

Acidified aspirin was administered in 24 hour fasted rats in a bolus dose of $60 \mathrm{mg} / \mathrm{kg}$ followed by a dose of $42 \mathrm{mg} / \mathrm{kg} / \mathrm{h}$ for a three hour period. Aspirin was dissolved in $0.15 \mathrm{M} \mathrm{HCl}$ and instilled intragastrically (through a plastic tube inserted surgically) into the stomach two hours before the start of the experiment as previously described. ${ }^{15}{ }^{17}$ After three hours of aspirin administration, the animals were killed and the area of all gastric ulcerations was measured planimetrically.

De-Nol (gift from Dr D W R Hall, Medical Department, Gist-brocades, Delft, The Netherlands) was dissolved in water and administered po in doses ranging from $2 \cdot 5-80 \mathrm{mg} / \mathrm{kg}$ about 30 minutes before the start of the administration of absolute ethanol or acidified aspirin. Sucralfate (gift from Dr E Gehrls, E Merck, Darmstadt, GFR) was suspended in water and used in doses ranging from $12 \cdot 5-400 \mathrm{mg} / \mathrm{kg}$. For comparison, 16,16 dimethyl $\mathrm{PGE}_{2}$ (gift from Dr J Pike, The Upjohn Co, Kalamazoo, Michigan) was used po in a standard protective doses $(10 \mu \mathrm{g} / \mathrm{kg})$.

\section{MEASUREMENT OF MUCOSAL GENERATION OF PROSTAGLANDIN}

The role of endogenous prostaglandin in the protection by De-Nol and sucralfate was examined in two ways: (1) by reversal of their gastroprotective effects by pretreatment with indomethacin $(5 \mathrm{mg} / \mathrm{kg} \mathrm{po})$ and (2) by directly measuring mucosal generation and luminal release of $\mathrm{PGE}_{2}$ using radioimmunoassay of $\mathrm{PGE}_{2}$. Immediately after killing the animals, the abdomen was opened and the stomach was clamped at the cardia and the pylorus. One millilitre of saline was then injected into the stomach and its contents collected for the measurement of luminal release of $\mathrm{PGE}_{2}$ using commercially available kits (New England Nuclear NEN, Dreieich, Germany). A large biopsy (about $50 \mathrm{mg}$ ) of the fundic mucosa was then obtained to determine the capability of the mucosa to generate $\mathrm{PGE}_{2}$ as previously described..$^{15} 17$

All experiments were carried out on Wistar rats
Table 1 Effects of De-Nol $(80 \mathrm{mg} / \mathrm{kg})$, sucralfate $(400$ $\mathrm{mg} / \mathrm{kg})$ or 16,16 dimethyl $P G E_{2}(10 \mu \mathrm{g} / \mathrm{kg})$ given po on gastric acid and pepsin secretion in chronic gastric fistula rats. Mean $\pm S E M$ of results obtained from 10 rats

\begin{tabular}{lll}
\hline Treatment & $\begin{array}{l}\text { Acidoutput } \\
\mu \text { mol } / 60 \text { min }\end{array}$ & $\begin{array}{l}\text { Pepsin output } \\
\mathrm{mg} / 60 \mathrm{~min}\end{array}$ \\
\hline Vehicle control & $416 \pm 48$ & $3 \cdot 12 \pm 0 \cdot 52$ \\
De-Nol & $386 \pm 62$ & $2 \cdot 84 \pm 0 \cdot 42$ \\
Sucralfate & $406 \pm 82$ & $2 \cdot 48 \pm 0 \cdot 68$ \\
16,16 dm PGE & $348 \pm 64$ & $3 \cdot 22 \pm 0 \cdot 60$ \\
\hline
\end{tabular}

fasted for 24 hours. Each series of experiments was repeated and each experimental group included eight to 10 animals.

\section{STATISTICAL ANALYSIS}

All values reported are the means $( \pm S E M)$. These means were used in the $t$ test for paired values to evaluate the significance of differences in gastric secretory output, ulcer area and prostaglandin generation.

\section{Results}

EFFECTS OF DE-NOL, SUCRALFATE AND A METHYLATED PROSTAGLANDIN ANALOGUE ON GASTRIC SECRETION

Table 1 shows the effects of the highest dose of DeNol, sucralfate and 16,16-dimethyl $\mathrm{PGE}_{2}$, used in the gastroprotective study, on gastric acid and pepsin

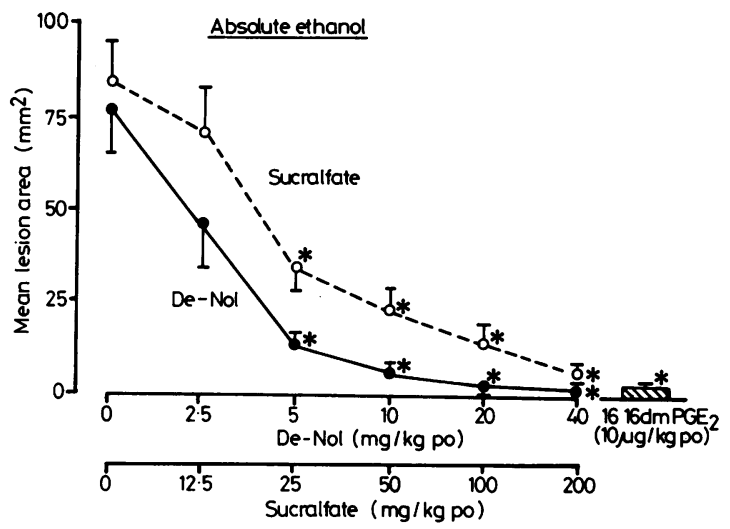

Fig. 1 Effects of De-Nol or sucralfate given po in various doses on mean lesion area induced by absolute ethanol. For comparison, the effect of po administration of a standard dose of 16,16 dimethyl $P G E_{2}$ on ethanol-induced lesions area is presented. In this and subsequent figures, each point represents mean $\pm S E M$ of results obtained from at least 10 rats. Asterisks indicate statistically significant $(p<0.05)$ differences from the control value obtained with vehicle $(1 \mathrm{ml}$ water) given po. 


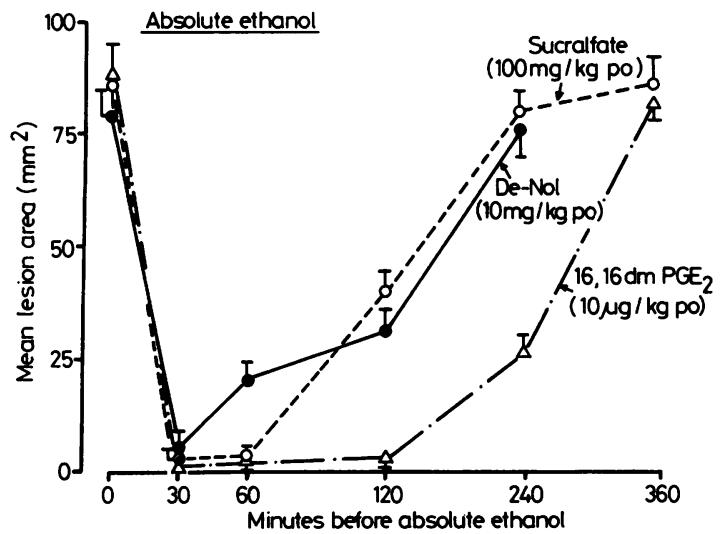

Fig. 2 Effects of De-Nol, sucralfate of 16,16 dimethyl $P G E_{2}$ administered po 30, 60, 120, 240,360 min before absolute ethanol on mean ulcer area induced by this ethanol.

secretion. None of these agents significantly affected acid or pepsin outputs from the chronic gastric fistula rats.

EFFECTS OF DE-NOL, SUCRALFATE AND METHYLATED PROSTAGLANDIN ANALOGUE ON ACUTE GASTRIC MUCOSAL LESIONS INDUCED BY ABSOLUTE ETHANOL AND ACIDIFIED ASPIRIN In control experiments without De-Nol or sucralfate, the mean lesions area induced by absolute ethanol averaged $76 \pm 10 \mathrm{~mm}^{2}$ and $83 \pm 10 \mathrm{~mm}^{2}$ (Fig. 1). Both De-Nol and sucralfate reduced dose dependently the severity of ethanol induced gastric necrosis, the dose reducing the mean lesion area by $50 \%\left(\mathrm{ID}_{50}\right)$ was

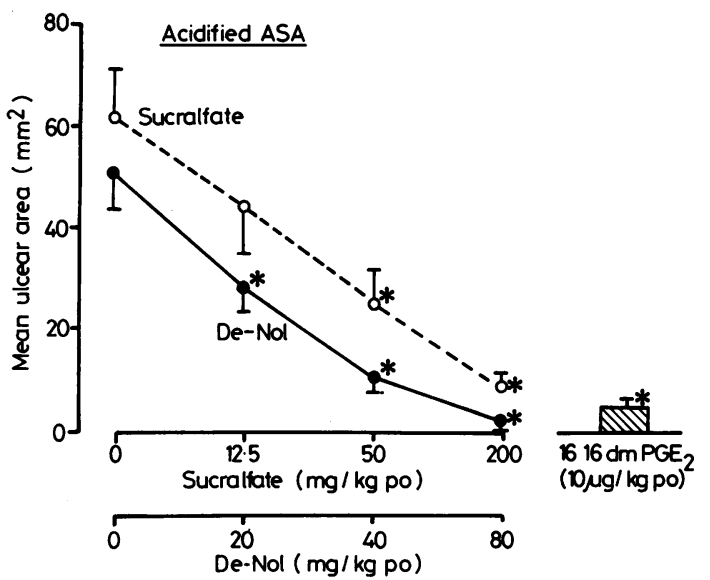

Fig. 3 Effects of De-Nol or sucralfate given po in various doses on mean ulcer area induced by acidified aspirin. For comparison, the effect of po administration of a standard dose of 16,16 dimethyl $P G E_{2}$ on aspirin-induced ulcer area is presented.
Table 2 Effects of De-Nol $(40 \mathrm{mg} / \mathrm{kg})$ or sucralfate $(100$ $\mathrm{mg} / \mathrm{kg}$ ) alone or in combination with indomethacin $(5 \mathrm{mg} / \mathrm{kg}$ ) given po 90 min earlier, on mean lesion area and lesion number induced by absolute ethanol

\begin{tabular}{lrcc}
\hline Treatment & $\begin{array}{l}\text { Rats } \\
(n)\end{array}$ & $\begin{array}{l}\text { Lesion area } \\
\mathrm{mm}^{2}\end{array}$ & Lesion number \\
\hline $100 \%$ Ethanol alone & 12 & $78 \pm 16$ & $15 \cdot 2 \pm 2 \cdot 6$ \\
$100 \%$ Ethanol+De-Nol & 8 & $2 \pm 1^{*}$ & $2 \cdot 1 \pm 0 \cdot 8^{*}$ \\
$100 \%$ Ethanol+sucralfate & 12 & $8 \pm 2^{*}$ & $3 \cdot 2 \pm 1.0^{*}$ \\
$\begin{array}{l}100 \% \text { Ethanol+De-Nol } \\
\quad \text { indomethacin }\end{array}$ & 9 & $61 \pm 12$ & $12 \cdot 4 \pm 1 \cdot 6$ \\
$\begin{array}{l}100 \% \text { Ethanol+sucralfate } \\
\quad \text { indomethacin }\end{array}$ & 9 & $60 \pm 11$ & $11 \cdot 8 \pm 2 \cdot 5$ \\
$\begin{array}{l}\text { 100\% Ethanol+indomethacin } \\
\text { Indomethacin alone }\end{array}$ & 8 & $82 \pm 24$ & $18 \cdot 6 \pm 2 \cdot 2$ \\
& 8 & $2 \pm 1$ & $0 \cdot 6 \pm 0 \cdot 2$ \\
\hline
\end{tabular}

*Significant $(\mathrm{p}<0.05)$ decrease from the control value obtained with $100 \%$ ethanol alone.

about $3 \mathrm{mg} / \mathrm{kg}$ and $22 \mathrm{mg} / \mathrm{kg}$, respectively. Methylated $\mathrm{PGE}_{2}$ at a standard dose of $10 \mu \mathrm{g} / \mathrm{kg}$ reduced the lesion area by about $95 \%$.

The duration of gastroprotective action of the drugs used is shown on Figure 2. The strongest protective effects of De-Nol and sucralfate were observed within the first 60 minutes after their administration. Their effects were reduced to about $50 \%$ after 120 minutes and disappeared almost completely after 240 minutes. 16,16 dimethyl $\mathrm{PGE}_{2}$ almost completely prevented ethanol-induced gastric necrosis and this effect disappeared after about $\mathbf{3 6 0}$ minutes.

Figure 3 shows the effects of De-Nol and sucralfate

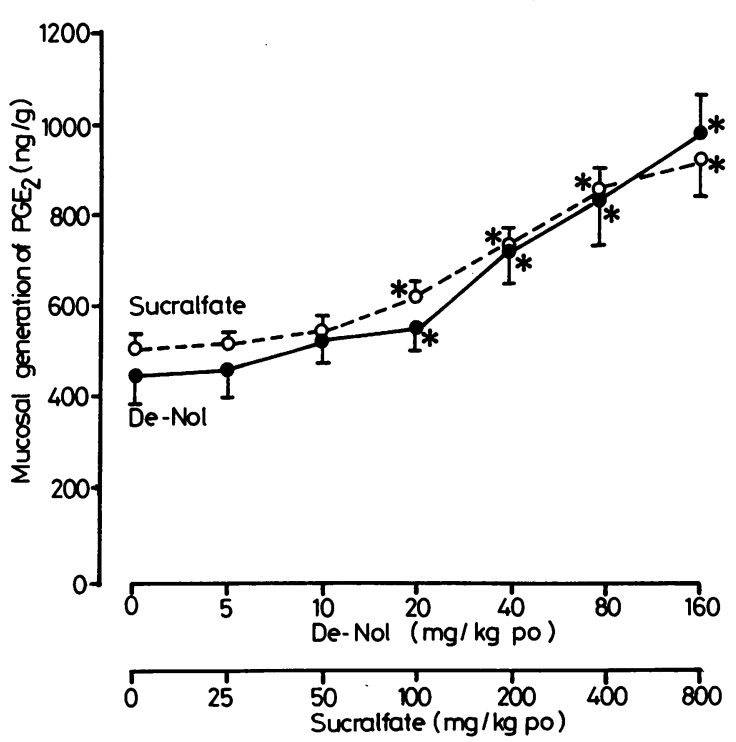

Fig. 4 Effects of various doses of De-Nol or sucralfate given po on mucosal generation of $P G E_{2}$ in intact rats. 


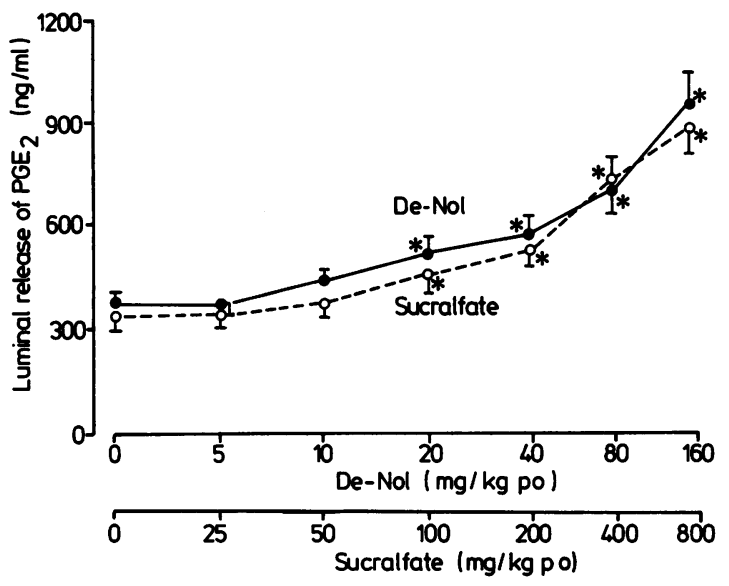

Fig. 5 Effects of various doses of De-Nol or sucralfate on luminal release of $P G E_{2}$ in intact rats.

on ulcers induced by acidified aspirin. Both agents dose dependently prevented the formation of aspirin-induced lesions, the ID $_{50}$ for De-Nol was about $24 \mathrm{mg} / \mathrm{kg}$ and that for sucralfate $41 \mathrm{mg} / \mathrm{kg}$. $\mathrm{PGE}_{2}$ analogue at a dose of $10 \mu \mathrm{g} / \mathrm{kg}$ almost completely prevented the production of aspirin induced ulcerations.

\section{EFFECTS OF DE-NOL AND SUCRALFATE ON PROSTAGLANDIN FORMATION IN GASTRIC $M U \cos A$}

In intact rats without administration of De-Nol or sucralfate, the capability of the mucosa to generate $\mathrm{PGE}_{2}$ averaged $480 \pm 60 \mathrm{ng} / \mathrm{g}$ wet tissue weight and the release of $\mathrm{PGE}_{2}$ into the gastric lumen was about $372 \pm 35 \mathrm{ng} / \mathrm{ml}$. As shown in Figures 4 and 5, De-Nol given po in increasing doses caused a dose dependent increase in the generation and release of $\mathrm{PGE}_{2}$ starting with the dose of $20 \mathrm{mg} / \mathrm{kg}$. Similarly, sucralfate caused an increase in $\mathrm{PGE}_{2}$ generation at doses $100 \mathrm{mg} / \mathrm{kg}$ and higher.

The results on the reversal of the protective effects of De-Nol against ethanol-induced lesions are presented in Table 2 . Indomethacin given po in a dose of $5 \mathrm{mg} / \mathrm{kg}$ failed to affect the integrity of the gastric mucosa. De-Nol in a dose of $40 \mathrm{mg} / \mathrm{kg}$ showed usual protection against absolute ethanol and this was almost completely reversed by the pretreatment with indomethacin given ig 90 minutes before the combination of De-Nol and ethanol. In similar studies with sucralfate, used in a dose $100 \mathrm{mg} / \mathrm{kg}$, the reversal of the protection by indomethacin with respect to the area and number of ethanol lesions was not significantly different from that obtained with De-Nol (Table 2).

\section{Discussion}

This study shows that De-Nol is effective in the prevention of the formation of acute gastric ulcerations induced by acidified aspirin and in the protection of gastric mucosa against acute necrotic lesions caused by absolute ethanol.

As in previous studies, ${ }^{12}$ we found that the antiulcer action of De-Nol against various ulcerogens is dose-dependent and similar to that of sucralfate but occurs at lower doses than sucralfate. This indicates that $\mathrm{De}-\mathrm{Nol}$ is several times more potent on a weight basis than sucralfate, a standard anti-ulcer drug. Because aspirin induced mucosal lesions depend on gastric acid secretion and can be prevented by potent inhibitors of this secretion such as ranitidine ${ }^{10}$ additional secretory tests were done to find out what effect, if any, De-Nol and sucralfate had on gastric acid secretion. It was found that both acid and pepsin secretions were similar in the vehicle and De-Nol or sucralfate treated rats. Thus, we exclude the mediation of decreased gastric acid secretion in the antiulcer effect of De-Nol or sucralfate.

This study shows for the first time that De-Nol, like sucralfate $^{12}$ is highly effective in the protection of gastric mucosa against acute necrosis induced by corrosive substances such as absolute ethanol. Although De-Nol produced a similar onset and duration of reduction of ethanol lesions as sucralfate, the dose of CBS was about 10 times lower. As this protection can be reversed by indomethacin, a potent inhibitor of prostaglandin biosynthesis, it may be assumed that mucosal prostaglandin are implicated. Direct support for this assumption was obtained from the studies with mucosal generation and luminal release of prostaglandin. Our study showed that both De-Nol and sucralfate administered into the intact stomach caused a dose-dependent increase in the ability of the fundic mucosa to generate $\mathrm{PGE}_{2}$ and in the release of this prostaglandin into the gastric lumen. It is likely that prostaglandin formed in large amounts account for the effects observed after DeNol or sucralfate including stimulation of mucusalkaline secretion, tightening the mucosal barrier ${ }^{3}$ and the increase in the mucosal resistance and mucosal cell renewal. ${ }^{12}$

The mediation by endogenous prostaglandin in the gastroprotective activities of sucralfate was previously proposed. ${ }^{12}$ The present study provides evidence that De-Nol also protects the gastric mucosa through increased biosynthesis of endogenous prostaglandin.

Both De-Nol and sucralfate have been shown to exhibit high efficacy not only in healing of gastroduodenal ulcerations but also in reducing the ulcer relapse rate. ${ }^{6-91314}$ Lower relapse rates appear to 
confer a therapeutic advantage on this gastroprotective agent when compared with agents acting through antisecretory mechanisms, such as $\mathrm{H}_{2}$-blockers. It remains to be established whether increased mucosal prostaglandin biosynthesis contributes to the therapeutic efficacy of these agents. ${ }^{49}$

\section{References}

1 Lavy U, Koekkoek PH, Jaitly KD. Anti-ulcer activity of colloidal bismuth subcitrate in Shay rats. Arch Int Pharmacodyn Ther 1976; 224: 291-8.

2 Wieriks J, Hespe W, Jaitly KD, Koekkoek PH, Lavy U. Pharmacological properties of colloidal bismuth subcitrate CBS, DE-NOL. Scand J Gastroenterol 1982; 17: suppl. 80: 11-16.

3 Lee SP. A potential mechanism of action of colloidal bismuth subcitrate: diffusion barrier to hydrochloric acid. Scand J Gastroenterol 1982; 17: suppl. 80: 17-21.

4 Coghill SB. Experimental studies using colloidal bismuth subcitrate: possible mode of action. In: Axon ATR, ed. Pathogenesis and the treatment of peptic ulcer disease. Amsterdam: Excerpta Medica, 1985: 7-12.

5 Marshall BJ, McGechie DB, Rogers PA, Gaancy RJ. Pyloric campylobacter infection and gastroduodenal disease. Med J Aust 1985; 142: 439-44.

6 Tytgat GNJ, van Bentem N, von Olffen G, Dekker W, Rutgeerts L, de Boer J. Controlled trial comparing colloidal bismuth subcitrate tablets, cimetidine and placebo in the treatment of gastric ulceration. Scand $J$ Gastroenterol 1982; 17: suppl. 80: 31-8.

7 Kang JY, Piper DW. Cimetidine and colloidal bismuth in treatment of chronic duodenal ulcer. Comparison of initial healing and recurrence after healing. Digestion 1982; 23: 73-8.

8 Lee FI, Samloff IM, Hardman M. Tripotassium dicitratobis-muthate TDB tablets compared with ranitidine in the acute healing and post healing release rates of patients with duodenal ulcerations. Lancet 1985; 1: 1299-302.

9 Hamilton I, O'Connor HI, Wood NJ, Bradburg I, Axen ATR. Healing and recurrence of duodenal ulcers after treatment with tripotassium dicitratobismuthate (TDB) tablets or cimetidine. Gut 1986; 27: 106-10.

10 Konturek SJ. Gastric cytoprotection. Scand J Gastroenterol 1985; 20: 543-53.

11 Okabe S, Takeuchi K, Kunimi H, Kanno M, Kawashima M. Effects of an antiulcer drug, sucralfate (a basic aluminium salt of sulfated disaccharide), on experimental gastric lesions and gastric secretion in rats. Dig Dis Sci 1983; 28: 1034-42.

12 Hollander D, Tarnawski A, Krause WJ, Gergely H. Protective effect of sucralfate against alcohol-induced gastric mucosal injury in rats. Gastroenterology 1985; 88: 366-74.

13 Hollander D. Efficacy of sucralfate for duodenal ulcers: a multicenter, double-blind trial. J Clin Invest 1981; 3: suppl. 2: 153-7.

14 McHardy GG. A multicenter, double-blind trial of sucralfate and placebo in duodenal ulcer. J Clin Gastroenterol 1981; 3: suppl. 2: 147-52.

15 Konturek SJ, Brzozowski T, Piastucki I, et al. Role of mucosal prostaglandins and DNA synthesis in gastric cytoprotection by luminal epidermal growth factor. Gut 1981; 22: 927-32.

16 Konturek SJ, Brzozowski T, Piastucki I, Radecki T. Prevention of ethanol and aspirin-induced gastric mucosal lesions by paracetamol and salicylate in rats: role of endogenous prostaglandins. Gut 1982; 23: 536-40.

17 Konturek SJ, Piastucki I, Brzozowski T, et al. Role of prostaglandins in the formation of aspirin-induced gastric ulcers. Gastroenterology 1981; 80: 4-9. 